\title{
Global Production Networks in Electronics and Intra-Asian Trade
}

\author{
Byron Gangnes \\ University of Hawai'i at Manoa \\ Ari Van Assche \\ HEC Montréal and LICOS
}

Working Paper No. 10-4

March 10, 2010

\begin{abstract}
The growth of East Asia's intra-regional trade is driven largely by increased component trade within global electronics production networks. Data on both electronics trade and production elucidate a pattern of specialization in which upper- and middle-income countries produce sophisticated components and lower-income countries assemble lowervalue-added final goods. There is evidence of increasing sophistication within the electronics sector by the Newly Industrialized Economies and to a lesser extent by ASEAN countries. Despite the marked increase in intra-regional trade, developing East Asian countries remain heavily dependent on developed-country markets. When Western export demand rapidly contracted during the 2008-2009 economic crisis, these specialization patterns led the rapid diffusion of the business cycle shock throughout the East Asian region.
\end{abstract}

Keywords: Global production networks; electronics; Asian trade; business cycle transmission; global economic crisis

JEL codes: F14, F23, F40, L63 


\title{
Global Production Networks in Electronics and Intra-Asian Trade
}

\author{
Byron Gangnes \\ University of Hawai'i at Manoa ${ }^{1}$ \\ Ari Van Assche \\ HEC Montréal and LICOS
}

\section{Introduction}

The last twenty years have seen a sharp rise in intra-regional East Asian trade. In 1980, trade among the nine major developing East Asian (EA-9) countries represented just 21\% of their total exports and $22 \%$ of their imports. ${ }^{2}$ By 2004, the intra-regional export share had risen to $40 \%$, and the import share to $47 \%$. Much of the growth in intra-regional trade has been driven by the growth of trade in electronics, which accompanied the rise of East Asia as the world's leading electronics producer. By 2004, trade in electronics represented \$326 billion of the total intra-regional manufactured trade of \$704 billion.

The growth and evolving structure of East Asian electronics trade reflect structural changes in the nature of electronics production. As electronic goods have become more modular, and as shrinking communication and transportation costs have reduced global distances, flagship companies in the U.S., Japan and Europe have increasingly fragmented their production processes and offshored their manufacturing activities to the Newly Industrialized Economies (NIEs). As labor costs started rising in the NIEs, firms have in turn offshored labor-intensive activities to less-developed East Asian countries, a phenomenon that has accelerated with the entry of China into global production networks.

The extensive integration of East Asian countries into global production networks for electronics products has unambiguously facilitated regional growth. But the uneven development paths taken by the various countries have also raised concerns. First, many of the Newly Industrialized Economies fear that the rise of other developing East Asian countries and especially China is hollowing out their economies. The ASEAN-4 and China, on the other hand, are concerned that they are stuck in the low-value-added production activities in the global production networks. Second, with the deepening intraAsian economic linkages and the increased reliance on electronics exports, the region has become increasingly dependent on final demand originating in the developed market economies and thus susceptible to industry and macroeconomic cycles.

'Correspondence: University of Hawai'i at Manoa, Department of Economics, 2424 Maile Way, Room 513 Honolulu, Hawai'i 96822. Phone: (808) 956-7285. E-mail: gangnes@ @awaii.edu. This paper was prepared for the SCAPE-EABER workshop,"IntraAsia Trade and Factor Flows: Trends, Determination and Implications," Singapore, 8-9 October 2007. We would like to thank Rodrigo Rodrigues and Porntawee Nantamanasikarn for excellent research assistance. Van Assche thanks the fonds québécois de la recherche sur la société et la culture (FQRSC) for financial support. ${ }^{2}$ The EA-9 include the four Newly Industrialized Economies (Hong Kong, Singapore, South Korea and Taiwan), the ASEAN-4 (Indonesia, Malaysia, Philippines and Thailand) and China. 
In this paper, we review the development of global production networks in electronics and East Asia's central role. We document the impact of these developments on emerging patterns of trade among the region's economies and between the region and the developed world. We analyze patterns of specialization both from the perspective of trade and also through the use of a unique database of electronics production statistics. While many of these issues have been discussed extensively in the literature, most existing studies look at overall patterns of trade. Our contribution is to focus specifically on trade in electronics components. And by considering data on production, we are able to shed clearer light on patterns of specialization that may be masked by the high volume of trade in intermediate components.

The organization of the paper is as follows. In Section 2, we describe how the fragmentation of production has contributed to the emergence of East Asia's electronics sector. We document evolving patterns of specialization and trade using electronics trade data in Section 3. Section 4 uses data on electronics production to evaluate the sophistication of electronics production in the region. Section 5 looks at how the growth of electronics trade has affected Asia-Pacific interdependence, and investigates the effect of the 2008-2009 global economic crisis on trade within global production networks. Section 6 concludes.

\section{East Asia and the Rise of Global Production Networks in Electronics}

Developing East Asia (The EA-9 economies comprising the Asian NIEs, ASEAN-4 and China) has emerged as a dominant global electronics manufacturing base over the past twenty-five years. ${ }^{3}$ As shown in Table 1, in 1985 the region was a small player, with national production levels of a few billion dollars or less, and with global production centered in the developed world. Between 1985 and 1995, the electronics sectors of many countries in the region experienced compound annual growth of 20-30\% or more, and the region's share of global electronics production reached $22 \%$. Rapid growth has continued since then, and in 2005 the EA-9 garnered $43 \%$ of world electronics production. ${ }^{4}$

\section{[Table 1 about here]}

The development of East Asia's electronics industry was initiated by the decisions of American and Japanese electronics firms to fragment their production processes internationally in response to a changing technological and competitive environment (Dedrick \& Kraemer 1998, Lowe \& Kenney 1999, Borrus, Ernst \& Haggard 2000). As electronics design became more modular and the costs of coordinating production over distance declined, U.S. and Japanese firms were able to locate less sophisticated production in lower-cost developing Asian economies (Sturgeon, 2002; Van Assche, 2008). This process accelerated as competition within the industry grew. The presence of foreign affiliates in Asia expanded rapidly, and production and trade relationships

${ }^{3}$ This section draws on the discussion in Bonham, Gangnes \& Van Assche (2007). ${ }^{4}$ Unlike production, electronics expenditure has remained concentrated in the developed world, with the share of electronics expenditure to GDP remaining substantially higher in the U.S., Japan and the E.U. than in developing East Asia. 
developed between and among East Asian economies as well. The East Asian region became a key part of the emerging global electronics production networks.

The landmark event in this process was the introduction of the IBM personal computer in the early 1980s, which dramatically increased the incentives for electronics firms to fragment the computer production process internationally (Ernst 2004). ${ }^{5}$ Before the PC, electronics companies built computers with fully closed proprietary architectures. The closed systems implied a high cost of coordinating interoperability between components and induced firms to produce almost everything - semiconductors, hardware and operating systems - in-house and usually within one country (Dedrick \& Kraemer 1998, Chandler 2001). The modular product architecture of the IBM PC changed all this. The standards of compatibility and interoperability among components of the PC were fixed and publicly known (Langlois \& Robertson 1995). Stages of the production process became separable from one another, and the costs of coordinating activities across the various stages fell dramatically. It became feasible and economically advantageous to site each piece of the production process where it could be produced at lowest relative cost, prompting a gravitation of labor-intensive stages to low-wage Asian economies.

The modular structure of the PC also drove fragmentation in another way. Once the de facto standards of interoperability and compatibility were set, barriers to entry were substantially reduced, and thousands of producers of IBM clones and components entered the market. The resulting competition drove down prices in almost all areas (Langlois \& Robertson 1995). In order to survive in the new highly-competitive environment, electronics producers were compelled to reduce production costs by moving laborintensive production blocks to East Asia (Dedrick \& Kraemer 1998). And, over time, as component prices continued to fall, labor costs became a bigger share of PC production costs (Curry \& Kenney 1999), further increasing the pressure to reduce costs through international fragmentation.

East Asia became the focus for much of the electronics offshoring for several reasons. First, the region already had a track record in electronics production, having produced for the consumer electronics industry during the late 1960s (Lowe \& Kenney 1999). In addition, many East Asian economies were viewed as attractive because they had both an abundant supply of low-wage labor and a large and growing pool of high-skilled engineers. Compared with many other developing regions, East Asia enjoyed a relatively stable political and macroeconomic environment, conducive to long-term investment projects and business relations (Yusuf 2001). Economic policies became more supportive during the 1980s and 1990s, as East Asian countries adopted export-oriented growth strategies, reduced trade and investment barriers, and deregulated domestic economic activities such as insurance, banking and transportation. Low trade barriers are particularly important for international production fragmentation, since goods may need to cross borders multiple occasions during the production process (Hummels, Rapoport \& Yi 1998; Yi 2003).

${ }^{5}$ Theoretical discussions of international production fragmentation include Jones \& Kierzkowski 1990 and Jones \& Kierzkowski 2001. Related to this is the economics literature on vertical foreign direct investment (Helpman 1984, Helpman 1985). 
At the same time, there have been changes in the global economic environment that have facilitated production fragmentation. Global transportation costs for distant travel and time-sensitive goods have declined over the past several decades (Hummels 2007; Behar \& Venables, forthcoming), benefiting the international trade of goods produced in internationally fragmented production processes where just-in-time linkages are important. A sharp decline in air shipping costs and improved ocean freight shipping have reduced the cost of distant relative to proximate transport, lowering costs of trade between East Asia and the United States. In addition to cheaper shipping, vastly cheaper communication technologies have become available, including inexpensive international telephone service, facsimile machines and the internet. These have enhanced the coordination, management and monitoring of activities in different locations.

The development of global production networks in electronics has proceeded in stages, first with the movement of labor-intensive production activities by U.S., European, and Japanese producers to the NIEs and ASEAN-4 countries. This can be seen in Table 1 in the high compound annual growth rates of these countries during the 1980s. As electronics producers in the NIEs gained in expertise, and as their labor costs rose, a second wave of offshoring occurred to lower-wage Asian countries. By the 1990s, the big story was the integration of China into the electronics global production networks (See, for example, Amighini 2005; Gaulier, Lemoine \& Unal-Kesenci 2007; and Gangnes \& Van Assche, 2010.) In some market segments, this new round of outsourcing has been dramatic: by early 2004, 70\% of Taiwanese notebook computers were being produced in China (Yang 2006). For observers in other East Asian economies, this of course raises questions about the impact of China's growing presence and its implications for regional production and trade.

\section{Patterns of Electronics Specialization and Trade}

The growth of electronics trade in East Asia has substantially surpassed the growth of electronics production. As shown in Table 2, developing East Asia's electronics exports expanded at a compound annual rate of $18 \%$ between 1980 and 2004 . World electronics exports grew at a slower $12 \%$ rate, so that by 2004 the EA-9 share of world electronics exports had grown to $49 \%$, from just $13 \%$ in 1980 . By 1990, the region had surpassed both the U.S. and Japan as an electronics exporter, and by 2004 the region's electronics exports at $\$ 702$ billion were more than the combined total of the U.S., Japan and the European Union.

\section{[Table 2 about here]}

The very rapid growth of East Asia's electronics trade was accompanied by a rise in the importance of intra-regional trade (Table 3). In 1980, only 23\% of EA-9 electronics exports went to other EA-9 countries, and only $26 \%$ of imports came from other EA-9 countries. By 2004, $46 \%$ of exports were intra-regional, and fully $68 \%$ of imports. The biggest external export market for East Asian producers continues to be the U.S., although both the EU and Japan have risen in relative importance. Japan plays a dominant role as a source of extra-regional imports, but the U.S. is also very important.

[Table 3 about here] 
As Asian producers have become integrated into global production networks, clear patterns of specialization and trade have emerged. Table 4 shows export and import shares both within and outside of the region. We divide electronics products into intermediate and final goods categories, giving us a rough indicator of which countries and regions specialize primarily in assembly operations and which specialize in the production of components. ${ }^{6}$ Not surprisingly, the U.S. and EU-15 dominate final goods demand, purchasing a combined $42-50 \%$ of the final goods exports of the NIEs, ASEAN-4 and China. The U.S. market is particularly important for ASEAN countries (especially Malaysia). Japan is even more dependent on American markets, with $57 \%$ of its final electronics products destined for the U.S. Imports of final goods come largely from the NIEs and China. ${ }^{7}$

\section{[Table 4 about here]}

The picture for intermediate goods looks somewhat different. The NIEs are the most important source of intermediate electronics imports, but they are also the leading destination for component exports. Japan, the U.S., China and ASEAN all export a substantial portion of their component production to NIEs. The NIEs in turn export heavily to China, as well as to other NIE countries. Hong Kong takes the largest share of these component exports by the NIEs, but there are significant bilateral flows in virtually all directions.

These trade patterns can be explained by a familiar comparative advantage story, applied to the vertically-fragmented electronics industry. Labor-abundant China is heavily specialized in the assembly of final products, which are exported to the U.S. and E.U. ASEAN countries also are significant final goods exporters. The production of intermediate goods - which we will see below is typically a more sophisticated activity than assembly - is dominated by the NIEs, economies which have considerable physical and human capital. The high-wage developed economies play only a limited role in

${ }^{6} \mathrm{We}$ construct nine subcategories based on three and four digit SITC Rev. 2 data. Four of the nine are judged to be predominantly "Intermediate Goods" and the remaining five categories are primarily "Final Products". "Intermediate Goods" comprise SITC 759 (Parts of and accessories suitable for office machines and automatic data processing machines \& units), 764.9 (Parts of apparatus of division 76-), 772 (Elect. app. such as switches, relays, fuses, ..., referred to as passive components) and 776 (thermionic, cold \& photo-cathode valves, tubes,..., referred to as active components). "Final Products" include 751 (office machines), 752 (automatic data processing machines \& units), 761 (television receivers), 764.1 (elect. line telephonic \& telegraphic apparatus), and 764.2 (microphones, loudspeakers, amplifiers). Trade data for two three-digit electronics categories was excluded from our analysis, because no data for the category was provided in the Statistics Canada World Trade Analyzer (763, television and sound recorders) or the available data was not sufficiently detailed to permit subdivision between intermediate and final goods (762 radio-broadcast receivers).

${ }^{7}$ The particularly large figures for trade between the NIEs and China reflect in part trade between China and Hong Kong. Roughly half of China's imports of final electronics come from Hong Kong and about two-thirds of the NIEs imports from China represent Hong Kong demand. 
electronics production, specializing instead in product design and marketing, activities that do not show up in merchandise trade figures.

A clearer view of the intensity of electronics industry specialization can be seen using revealed comparative advantage (RCA) indices. Measures of export RCA are often used to help assess a country's export specialization. A value that exceeds unity implies that the country has a greater than average share of electronics exports in that category. ${ }^{8} \mathrm{Ng} \&$ Yeats (2001) argue that a similar import RCA index can be used as a reliable predictor of specialization in final product assembly. A country that specializes in the export of final assembly is likely to import more than proportionately parts and components in that sector. It follows that countries with above average import shares for components in a sector are relatively heavily specialized in assembly operation. Export RCA indices for East Asian electronics are given in Table 5; import RCAs are given in Table 6.

\section{[Table 5 about here]}

\section{[Table 6 about here]}

The RCA indices confirm the very different roles played by the ASEAN-4 countries (and China), the NIEs, and the U.S. and Japan. For the ASEAN-4 countries, export RCA indices for final goods categories average above 1, indicating that for these low-to-middle income countries final goods make up a larger-than-average share of their electronics exports. Their export RCA indices for intermediate goods average below one. Import RCAs for ASEAN-4 show the opposite pattern: high import intensity in intermediate goods and lower-than-average imports of final goods. Note that China appears quite similar to the ASEAN-4 economies, although even more specialized as a producer of final goods. This pattern is consistent with the notion that less-developed East Asian economies specialize in the labor-intensive assembly of final electronics products.

On the other end of the spectrum are the U.S. and Japan, which display high final good import intensities and intermediate good export intensities. These rich-country economies are specialized in the production of components, particularly semiconductors, and serve as dominant markets for final goods.

Consistent with the results of the regional trade flow analysis, the NIEs appear to occupy a pivotal middle ground. These economies exhibit high intermediate good intensity on both the import and export side. This pattern is consistent with the NIEs

${ }^{8}$ The export RCA index is calculated as the ratio of two ratios, the ratio of exports for each subsection of electronics in an economy to that economy's total electronics exports, relative to the ratio of world exports for each corresponding section to world total electronics exports. The index reveals the pattern of export specialization for an economy relative to worldwide patterns. The greater a sector's RCA, the more an economy specializes in that sector's exports relative to world specialization patterns. The import RCA index is defined analogously. While such indices by definition measure the degree of specialization of exports in product categories, the term "revealed comparative advantage" is an unfortunate misnomer. Because trade may be highly distorted by trade barriers and implicit or explicit domestic taxes and subsidies, such measures may "reveal" little about the actual comparative advantage of countries. 
intermediate role within electronics production value chains. They source relatively unsophisticated parts from lower-wage Asian economies that they use to produce more sophisticated electronics components. They then supply these components to China and other lower-wage Asian economies for final assembly. ${ }^{9}$

\section{Product Sophistication and Upgrading}

A key research question of interest to many policy makers is which countries are responsible for the high-value-added production activities in global value chains and which countries are stuck with the less profitable low-value-added activities. A number of studies by Lall (2006), Rodrik (2006) and Hausmann, Hwang \& Rodrik (2007) have recently tried to gain insights into this issue by estimating the revealed sophistication of a country's export composition. The starting point of these studies is that a country's production activities are more sophisticated if its export composition more closely resembles that of high income countries. The rationale behind this is that richer countries generally have characteristics that provide a comparative advantage in more-advanced industries. These characteristics may include high capital abundance, the embodiment of higher-level technology and better institutions. As developing countries improve these characteristics, they will gradually create comparative advantages in the same industries as the richer countries.

As we have argued in Van Assche \& Gangnes (2010), there is a key shortcoming of using export data to estimate a country's position on the technological ladder. Export data are collected and reported as gross flows rather than as value added created in the exporting country. In a world with international production fragmentation and intermediate good trade, a country's exports therefore do not necessarily reflect the embodied technology and relative endowments that have gone into the country's domestic production activities, but may simply reflect the technology and factors of the countries from which it imports intermediate goods. This may be a particularly large problem in the East Asian region where intermediate good trade plays such a large role in trade patterns.

A more appropriate tool to estimate a country's degree of sophistication is production data. In this section, we estimate the degree of sophistication of the East Asian countries' electronics industries by making use of a unique data set of world electronics production

\footnotetext{
${ }^{9}$ There are interesting exceptions to these general observations for specific subcategories, presumably reflecting specialization patterns across market segments and idiosyncratic factors. For example, Malaysia and the Philippines have high export RCAs in active components (semiconductors), but these are likely lower value added memory chips and standardized components. The U.S. has relatively high export intensity in the final good categories of office machines, telephone/telegraph and sound equipment, probably catering to more-sophisticated market segments. The ASEAN-4 and China export relatively few televisions - due to the large role of Mexico and Eastern European countries in the mainstream market - while Japan exports more televisions than expected, presumably higher-end models. This represents a limitation of the fairly-aggregate product classification scheme we have used, dictated by data available in the Statistics Canada data set.
} 
compiled by Reed Electronics Research. ${ }^{10}$ The Reed Electronics Production Data Set (REP) measures a country's domestic production by electronics subcategories for fiftyone countries. The coverage and degree of disaggregation in the REP varies between countries, but we have been able to extract a consistent panel for nine electronics subcategories from 1992 to 2005 that is in line with our definition of electronics above (See Table 7 for the list of product subcategories).

\section{[Table 7 about here]}

To analyze the relative degree of sophistication of the East Asian countries' electronics sectors, we use the same methodology as Hausmann, Hwang \& Rodrik (2007), albeit with production data instead of trade data. In a first step, we estimate the level of technological sophistication of an electronics subcategory as the weightedaverage income of its producers. Let $x_{i, c}$ denote the production value of electronics subcategory $i$ in country $c, X_{c}=\sum_{i} x_{i, c}$ equal country $c$ 's total electronics production value and $Y_{c}$ represent country $c$ 's per-capita GDP in current prices. Then the level of product sophistication $S$ for good $i$ is given by

$$
S_{i}=\sum_{c} \frac{x_{i, c} / X_{c}}{\sum_{c}\left(x_{i, c} / X_{c}\right)} Y_{c} .
$$

Once the sophistication index has been estimated for all electronics subcategories $i$, one can then in a second step calculate a country's technology index CTI as the weighted average of the sophistication levels of the electronics subcategories that it produces:

$$
C T I_{c}=\sum_{i} \theta_{i, c} S_{i}
$$

where a product's weight $\theta_{i, c}$ equals the share of good $i$ in country $c$ 's total electronics output:

$$
\theta_{i, c}=\frac{x_{i, c}}{X_{c}}
$$

In Table 8 , we present the sophistication indices $S_{i}$ for the various electronics subcategories in 1992 and 2004 respectively. For ease of analysis, the degree of sophistication of each electronics subcategory is reported relative to that of the most sophisticated subcategory, Radio Communications \& Radar. For the same purpose, we have grouped the nine electronics subcategories into the three more general categories Communications, Components and Computers, Audio \& Video (CAV).

\footnotetext{
${ }^{10}$ Production data could be subject to the same difficulty in identifying value added as opposed to the value of gross sales, which could in some cases, "amount to little more than assembly of imported piece-parts and sub-assemblies." The problem is likely smaller than for export values, however, since goods are counted in production only when "value is added in the assembly process and the finished article can be classified under a different SIC Standard Industrial Classification) from those of its components." (Reed Electronics Research 2007)
} 


\section{[Table 8 about here]}

We can use Table 8 to make a couple of observations. First, it is striking that within the electronics industry there is a wide variation in sophistication. Video equipment and audio equipment, for example, have degrees of sophistication that are just 39 percent and 53 percent of that of radio communications \& radar. Second, if we compare the degree of sophistication of the three major categories, we obtain the result that Communications is more sophisticated than Components and $C A V$ in that order. It is noteworthy, however, that the relative sophistication of $C A V$ has dropped significantly during the twelve year period (see Figure 1). In 1992, its relative degree of sophistication was 0.84, while in 2004 it had declined to 0.75 . This drop is not due merely to the rapid rise of China's EDP production. Rather, it represents a more general trend of production specialization in $C A V$ by developing countries including China, the ASEAN-4 countries, Mexico and a number of Eastern European countries. As mentioned above, one of the main drivers of this trend is likely the large-scale offshoring of EDP assembly plants by multinational firms to developing countries made possible by changes in technology and the economic environment that facilitated the vertical fragmentation of computer production.

\section{[Figure 1 about here]}

With this relative sophistication index in mind, we can analyze the degree of sophistication of East Asian countries' electronics production activities. In Table 9, we depict the production intensity indices for the various East Asian countries in the three electronics categories. A production intensity index is the same as an RCA index, except that it uses production data instead of trade data. In other words, a number larger than one implies that a country produces relatively more of that electronics category than the rest of East Asia. A number smaller than one suggests that a country is less specialized than the rest of Asia in that category. ${ }^{11}$

\section{[Table 9 about here]}

The 2004 production intensity indices confirm that, within the East Asian region, the richer economies generally specialize in the production of the more sophisticated electronics products. Japan and the NIEs are specialized in the high sophistication category Communications. ${ }^{12}$ Japan, the NIEs and the ASEAN-4 are specialized in the medium sophistication category Components and the ASEAN-4 and China are specialized in the low sophistication category $C A V$.

Between 1992 and 2004, Japan and the NIEs have generally upgraded their production composition by reducing their specialization in $C A V$ and sustaining or increasing their specialization in Communications and Components. The ASEAN-4 has primarily increased its specialization in Components at the cost of Communications. China, finally, has increased its concentration in $C A V$.

\footnotetext{
${ }^{11}$ We present the more disaggregated set of production intensity indices that we use in the calculation of the CTI index in the appendix.

${ }^{12}$ These results differ for the four NIE countries. Singapore, for example, has been least specialized in Communications of all East Asian countries.
} 
In a final step, we can use equation 2 to calculate the country technology indices (CTI) for the 51 countries included in the REP data set. In Figures 2 and 3, we show the scatter plot of CTI against per-capita GDP for the East Asian countries in 1992 and 2004. A number of observations stand out from the graphs. First, with the exception of South Korea in 1992 and the Philippines in 2004, it is generally the case that the CTI of the more developed East Asian economies Japan and the NIEs exceeds that of the less developed East Asian economies in the ASEAN-4 and China. The reason behind South Korea's low CTI in 1992 is their high specialization in the low sophistication categories of audio and video equipment. The reason behind the Philippines' high CTI in 2004 is their high specialization in active components. Second, South Korea is the country that has improved its ranking most significantly between 1992 and 2004. It has moved up from 7 th to 1 st place due to its heightened specialization in radio communications and radar, and despecialization in audio and video equipment. The largest loser has been Hong Kong (from 2nd to 6th) due to its despecialization in radio communications and radar. Finally, it is noteworthy that China's CTI is comparable to that of the ASEAN-4 countries Malaysia and Thailand. Contrary to more aggregate trade-based results, China's electronics production does not appear to be more sophisticated than one would expect given its level of economic development.

\section{[Figure 2 about here]}

\section{[Figure 3 about here]}

Our analysis confirms that the richer economies in the East Asian region specialize in the production of the more sophisticated electronics products. It also suggests that the rise of China is not necessarily threatening the other East Asian countries' economies, but that Japan, the NIEs and to a lesser extent the ASEAN-4 have been able to upgrade to more sophisticated production activities over time. These more sophisticated production activities include components, but also some higher-value-added final goods such as radio communications and radar.

\section{Electronics Trade and Asia-Pacific Interdependence}

The buildup of East Asia's electronics industry has been an important component of the region's rapid growth over the past two decades. However, the dramatic rise in electronics specialization has also raised the concern of increased vulnerability of these economies to industry cycles and to broader business cycle fluctuations in the developed world. In his book, End of the Line, Barry Lynn gave a nice example to demonstrate this vulnerability. On September 21, 1999 an earthquake slammed through Taiwan and shut down its main electronics hub Hsinchu Science Park for a week (Lynn 2005). The oneweek shutdown affected companies around East Asia and the world that relied on Taiwanese components and cut world output of electronics in October by 7 percent below predictions.

The electronics industry is prone to more severe cyclical fluctuations than regular business cycles, arising from the uneven pace of technical progress, changes in leading products, and demand conditions in consuming countries (Kumakura 2005, Chow \& 
Choy 2006, Engel \& Wang 2008). According to data compiled by Kumakura (2005), new orders for electronics typically swing from positive annual growth rates of about $30 \%$ to contractions of $5-10 \%$ in the space of a single year; swings in semiconductor sales are even more pronounced. The 2001 industry slump saw both semiconductor sales and electronics orders fall by about $30 \%$ in one year. ${ }^{13}$ Engel and Wang (2008) show that U.S. durable goods imports such as electronics are more sensitive to business cycles than nondurable goods imports.

These cycles have notable effects on aggregate export performance of East Asian economies. We can use electronics trade data to gauge the extent of national exposure to electronics industry cycles. Table 10 shows the shares of electronics in overall manufactured exports for each of the EA-9 countries, the U.S., EU-15 and Japan. The electronics export share for the East Asian region is roughly twice as large as that of the world as a whole, and it has risen significantly since 1980. In all countries but Indonesia, electronics represent more than $30 \%$ of total manufactured exports, with export shares of about $60 \%$ for Singapore and Malaysia. Export shares for final electronics products are 2-5 times larger than for the U.S., EU-15 and Japan.

\section{[Table 10 about here]}

In addition to vulnerability to cycles within the electronics industry, high dependence on large developed-country markets-particularly in the United States-represent another source of vulnerability. Table 11 shows export volumes relative to GDP. Figures are reported for total electronic exports, exports of electronics final goods, and final goods exports to the U.S. Not only are electronics exports large relative to GDP, but a number of countries in East Asia have a significant economic dependence on the U.S. economy through their electronics final goods exports to the U.S. market. In the case of Singapore and Malaysia this dependence appears to be very large. (However, their high volume of component imports suggests trade data for these countries may be misleading, as we discuss below.) Dependence on the U.S. market remains high despite the growth of intra-Asian trade..$^{14}$

\section{[Table 11 about here]}

\footnotetext{
${ }^{13}$ We are aware of only a small number of formal studies of the role of the electronics industry in international business cycles. Abeysinghe (2000) analyzes the global electronics cycle and its impact on Singapore. Chou, Gau \& Liang (2007) study supply and demand factors in the linkage between US and Taiwanese electronics industries. The importance of electronics industry cycles in Asia has been studied as a proximate cause in the development and transmission of the 1997 Asian Financial crisis; Daraisami (2004) looks at the case of Malaysia. Kumakura (2005) find that adjusting for electronics industry cycles can change empirical conclusions about the impact of China on the trade of other East Asian economies and on the role of exchange rate fluctuations in East Asian trade.

${ }^{14}$ This point has been made in a more general context by Athukorala \& Yamashita (2006) and Abeysinghe \& Forbes (2001).
} 
One has to be careful, however, in using export share data to measure a country's degree of vulnerability. Overall shares of electronics exports may exaggerate the extent of economic vulnerability because of the preponderance of trade in intermediate goods. As we have noted above, a considerable and rising proportion of electronics trade involves cross-hauling of parts and components between countries, sometimes with limited value added created before re-export. An extreme case of this is China, where "processing trade" - the assembly of imported components for exports - represent more than half of all exports and 90\% of electronics exports (Ma, Van Assche \& Hong, 2009; Ma \& Van Assche, 2009). Domestic value added in Chinese processing trade remains low, accounting for less than $15 \%$ for electronic and communication equipment (Koopman, Wang and Wei, 2008), although these margins have increased in recent years (Cui \& Syed 2007). If value added in an economy's electronics sector is limited, then the aggregate economic impact of a drop-off in export growth will be smaller than it might appear. There will be an accompanying drop in the country's import demand for components, thus leading to a business cycle pass-through effect.

At the same time, countries specialized in components exports can also face significant downward economic impacts from, say, a downturn in the American market even if they export relatively small amounts of final goods to the U.S. The downturn in demand would reduce electronics production through reduced demand for component exports to third country producers of final goods bound for the American market. ${ }^{15}$

Ma \& Van Assche (2009, forthcoming) have used data on China's processing trade to provide preliminary evidence of business cycle pass-through effects within global production networks in the context of the 2008-2009 global economic crisis. Data on China's processing trade regime are particularly useful for this purpose since, by its nature, firms under this regime are granted duty exemptions on imported raw materials and other inputs as long as they are used solely for export purposes. This allows one to investigate how a change in demand for Chinese processing exports affects China's demand for processing imports. Such analysis cannot be conducted with regular trade data since imports are not necessarily used solely for export purposes.

As it is shown in Table 12, the effect of the economic crisis on China's processing trade has been large. In the first quarter of 2009, demand for China's processing exports experienced a stunning contraction of $23.7 \%$ compared to a year earlier. Interestingly, the negative export demand shock seems to have been amplified as it moved upstream from processing exports to processing imports, with China's processing imports dropping an even larger $36.2 \%$. This amplification effect is not only observed in aggregate trade, but also across industries. This is in line with the bullwhip effect that is often witnessed in global supply chains (Lee, Padmanabhan and Wang, 1997; Cachon, Randall and Schmidt, 2007). When a drop in final demand reduces downstream activities, a firm's first reaction is to run down its inventories. Thus a slowdown in downstream activities transforms itself into an amplified reduction in the demand for inputs that are located upstream.

\section{[Table 12 about here]}

\footnotetext{
${ }^{15}$ As the Taiwan earthquake example illustrates, electronics industry vulnerabilities also exist on the supply side. Supply factors were seen to be important components of international linkages between the U.S. and Taiwan by Chou, Gau \& Liang (2007).
} 
The business-cycle pass-through effect in China's processing trade has hit most severely China's imports from countries that more intensively supply China with its processing inputs, that is, its East Asian neighbors. As shown in Figure 4, with the exception of Vietnam and Indonesia, more than $40 \%$ of China's imports from its major East Asian trading partners were processing imports in 2006, which is a significantly higher share than for countries outside of East Asia. These East Asian countries have witnessed the largest import decline during the recent global economic crisis. Compared to the previous year, China's imports from its major East Asian trading partners all declined between $25 \%$ and $61 \%$ in the first quarter of 2009. In contrast, China's imports from its major non-Asian trading partners dropped less than $20 \%$.

\section{[Figure 4 about here]}

These empirical findings suggest that business cycle shocks are rapidly transmitted internationally through global production networks (Burstein, Kurz and Tesar, 2008). This business cycle pass-through effect can help explain the large drop in intra-Asian trade that was registered during the crisis period, as well as the big decline in world trade (Tanaka, 2009; Yi, 2009; Escaith, 2009). More research, however, is needed on this topic. The complex nature of trade linkages, and the endogeneity of price and output responses, means that such casual inspection of trade data is unlikely to give a complete picture of the dependence of East Asian economies on the electronics industry or on large richcountry consumer markets. What is needed is systematic modeling of electronics production and trade within the context of a international macroeconomic model. There appears to be little work yet of this kind. ${ }^{16}$

\section{Conclusions}

Global production networks are at the heart of the East Asian electronics industry. Over the past several decades, multinational electronics firms have sliced up their value chains and have dispersed their production activities across the globe, with the lion's share in East Asia. As we have seen, this large-scale reorganization of international production has not only altered the patterns of trade across the region, but has also affected many East Asian countries' growth paths. In this paper, we have emphasized the point that comparative advantage continues to explain trade patterns, but within the context of globally-fragmented value chains.

At the same time, there are a number of new research questions that arise when thinking about global production networks. First, there is a need to analyze in more detail the mechanisms through which countries are able to upgrade into higher-value-added activities within a global production network. How is value distributed throughout a network, and what drives the process of technological upgrading by countries? In addition, we need to examine more carefully the ways in which these global production networks affect the vulnerability of countries.

The global economic crisis has brought a new question to the fore: the sustainability of global production networks in the post-crisis era. Some observers predict that recent

\footnotetext{
${ }^{16}$ Abeysinghe \& Forbes (2001) use trade patterns to inform a structural VAR model of output interactions among these countries and regions.
} 
macro-economic events and technological advances threaten to reverse this trend of international production fragmentation, thus making global production networks more local. First, the era of cheap and plentiful oil seems to have drawn to a close, thus leading to increases in transportation costs (Rubin, 2009). Second, the global economic crisis of 2008-2009 has put pressure on many governments to adopt protectionist measures that privilege domestic over foreign production and that raise trade and investment barriers (Baldwin and Evenett, 2009). Finally, the adoption of just-in-time production techniques (associated with reductions in communication costs) has enticed firms to source their time-sensitive components closer to home (Evans and Harrigan, 2005; Harrigan and Venables, 2006). Since international production fragmentation is considered especially sensitive to changes in such transaction costs (Yi, 2003), these trend reversals could entice flagship electronics firms that are supplying Western markets to on a large scale rethink their global supply chains and abandon far away production for closer locations. If these predictions play out, this could have profound impacts on intra-Asian trade patterns. 


\section{References}

Abeysinghe, T. (2000), 'Electronics and growth cycles in Singapore', Applied Economics 32, 1657-63.

Abeysinghe, T. \& Forbes, K. (2001), Trade linkages and output-multiplier effects: A structural VAR approach with a focus on Asia, Working Paper 8600, National Bureau of Economic Research.

Amighini, A. (2005), 'China in the international fragmentation of production: Evidence from the ICT industry', The European Journal of Comparative Economics 2, 203219.

Athukorala, P. \& Yamashita, N. (2006), Production fragmentation and trade integration: East Asia in a global context, North American Journal of Economics and Finance 17, 233-256.

Baldwin, R. \& Evenett, S. (2009). The collapse of global trade, murky protectionism, and the crisis: Recommendations for the G-20, VoxEU.org E-book, http://www.voxeu.org/reports/Murky_Protectionism.pdf

Behar, A. \& Venables, A. (forthcoming), Transport costs and international trade, in de Palma, A., Lindsey, R., Quinet, E. \& R. Vickerman, eds., 'Handbook of Transport Economics.' Edward Elgar.

Bonham, C., Gangnes, B. \& Van Assche, A. (2007), 'Fragmentation and East Asia's information technology trade', Applied Economics 39, 215-228.

Borrus, M., Ernst, D. \& Haggard, S. (2000), International Production Networks in Asia: Rivalry Or Riches? Routledge, London.

Burstein, A.,Kurz, C. \& Tesar, L. (2008), 'Trade, production sharing, and the international transmission of business cycles', Journal of Monetary Economics 55, 775-795.

Cachon, G., Randall, T. \& Schmidt, G. (2007), 'In search of the bullwhip effect', Manufacturing \& Service Operations Management 9, 457-479.

Chandler, A. D. (2001), Inventing the Electronic Century: The Epic Story of the Consumer Electronics and Computer Industries, The Free Press, New York.

Chou, W. L., Gau, J. J. \& Liang, K.-Y. (2007), 'Industrial business cycle linkages between Taiwan and the United States: Evidence from the IT industry', Journal of Asian Economics 18, 439-447.

Chow, H. K. \& Choy, K. M. (2006), 'Forecasting the global electronics cycle with leading indicators: A bayesian var approach', International Journal of Forecasting 22, 301-315.

Cui, L. \& Syed, M. (2007), The shifting structure of China's trade and production, Working Paper 214, International Monetary Fund.

Curry, J. \& Kenney, M. (1999), 'Beating the clock: corporate responses to rapid change in the PC industry', California Management Review 42, 8-36.

Daraisami, A. (2004), 'Export growth slowdown and currency crisis: the Malaysian experience', Applied Economics 36, 1947-57.

Dedrick, J. \& Kraemer, K. (1998), Asia's Computer Challenge: Threat or Opportunity for the United States and the World? Oxford University Press, Oxford.

Engel, C. \& Wang, J. (2008), International trade in durable goods: understanding volatility, cyclicality and elasticities, National Bureau of Economic Research Working Paper No. 13814. 
Ernst, D. (2004), Global production networks in East Asia's electronics industry and upgrading perspectives in Malaysia, in S. Yusuf, M. Altaf and K. Nabeshima, eds., 'Global Production Networking and Technological Change in East Asia', World Bank, Washington, D.C., Oxford University Press, 89-157.

Escaith, H. (2009), Trade collapse, trade relapse and global production networks: supply chains in the great recession, mimeo, http://mpra.ub.uni-muenchen.de/18433/.

Evans, C. \& Harrigan, J. (2005), 'Distance, time, and specialization: lean retailing in general equilibrium,' American Economic Review 95, 292-313.

Gangnes, B. and Van Assche, A. (2010), China and the Future of Asian Electronics Trade, Chapter 14 in Linda Yueh (Ed.), 'The Future of Asian Trade and Growth: Economic Development with the Emergence of China', Routledge, London, 351377.

Gaulier, G., Lemoine, F. \& Unal-Kesenci, D. (2007), 'China's integration in East Asia: Production sharing, FDI \& high-tech trade', Economic Change and Restructuring 40, 27-63.

Harrigan, J. \& Venables, A. (2006), 'Timeliness and agglomeration', Journal of Urban Economics 59, 300-316.

Hausmann, R., Hwang, J. \& Rodrik, D. (2007), 'What you export matters', Journal of Economic Growth 12, 1-25.

Helpman, E. (1984), 'A simple theory of international trade with multinational corporations', Journal of Political Economy 92, 451-71.

Helpman, E. (1985), 'Multinational corporations and trade structure', Review of Economic Studies 52, 443-57.

Hummels, D. L. (2007), 'Transportation costs and international trade in the second era of globalization,' Journal of Economic Perspectives 21, 131-154.

Hummels, D. L., Rapoport, D. \& Yi, K.-M. (1998), 'Vertical specialization and the changing nature of world trade', Federal Reserve Bank of New York Economic Policy Review 4, 79-99.

Jones, R. W. \& Kierzkowski, H. (1990), The role of services in production and international trade: A theoretical framework, in R. Jones \& A. Krueger, eds, 'The Political Economy of International Trade: Essays in Honor of Robert E. Baldwin', Blackwell, Cambridge, MA, 31-48.

Jones, R. W. \& Kierzkowski, H. (2001), A framework for fragmentation, in S. Arndt \& H. Kierzkowski, eds, 'Fragmentation: New Production Patterns in the World Economy', Oxford University Press, New York, 17-34.

Koopman, R., Wang, Z., \& Wei, S.-J. (2008), How much of Chinese exports is really made in China? Assessing domestic value-added when processing trade is pervasive, NBER Working Paper 14109.

Kumakura, M. (2005), Trade, exchange rates, and macroeconomic dynamics in East Asia: Why the electronics cycle matters, Discussion Paper 34, Institute of Developing Economies.

Lall, S.; Weiss, J. Z. J. (2006), 'The sophistication of exports: A new trade measure', World Development 34, 222-237.

Langlois, R. N. \& Robertson, P. L. (1995), Firms, Markets, and Economic Change: A Dynamic Theory of Business Institutions, Routledge, London. 
Lee, H., Padmanabhan, S., \& Wang, S. (1997), 'Information distortion in a supply chain: the bullwhip effect, Management Science 43, 546-558.

Lowe, N. J. \& Kenney, M. (1999), 'Foreign investment and the global geography of production: Why the Mexican consumer electronics industry failed', World Development 27, 1427-43.

Lynn, B. (2005), End of the Line: The Rise and Coming Fall of the Global Corporation, Doubleday, New York.

Ma, A., Van Assche, A. \& Hong, C. (2009), 'Global production networks and China's processing trade', Journal of Asian Economics 20, 640-654.

Ma, A. \& Van Assche, A. (2009), 'China's trade in crisis,' AIB Insights 9, 11-15.

Ma, A. \& Van Assche, A. (forthcoming), China's role in global production networks, mimeo.

Ng, F. \& Yeats, A. (2001), Production sharing in East Asia: Who does what for whom and why? in L. Cheng \& H. Kierzkowski, eds, 'Global Production and Trade in East Asia', Kluwer Academic Publishers, Boston, 63-109.

Petri, P. \& Plummer, M. (2009), 'The triad in crisis: what we learned and how it will change global cooperation', Journal of Asian Economics 20, 700-713.

Reed Electronics Research (2007), Guide to the interpretation of the statistics, mimeo.

Rodrik, D. (2006), 'What's so special about China's exports?' China and the World Economy 14, 1-19.

Rubin, J. (2009), Why your world is going to get a whole lot smaller: oil and the end of globalization, Random House.

Sturgeon, T. (2002), 'Modular production networks: a new American model of industrial organization', Industrial and Corporate Change 11, 451-496.

Tanaka, K. (2009), 'Trade collapse and vertical foreign direct investment', Vox, 7 May.

Van Assche, A. (2008) 'Modularity and the organization of international production, Japan and the World Economy 20, 353-368.

Van Assche, A. \& Gangnes, B. (2010), 'Electronics production upgrading: Is China exceptional?' Applied Economics Letters 17, 477-482.

Yang, Y. (2006), The Taiwanese notebook computer production network in China: Implications for upgrading of the Chinese electronics industry, Research workshop paper, Hong Kong University of Science and Technology Center on China's Transnational Relations.

Yi, K.-M. (2003), 'Can vertical specialization explain the growth of world trade?' Journal of Political Economy 111, 52-102.

Yi, K.-M. (2009), The collapse of global trade: the role of vertical specialization, in Baldwin and Evenett, eds., 'The Collapse of Global Trade, Murky Protectionism, and the Crisis: Recommendations for the G20', Vox, CEPR, London, 45-48.

Yusuf, S. (2001), The East Asian miracle at the millennium, in 'Rethinking the East Asian Miracle', Oxford University Press, New York, pp. 1-53. 


\section{Figure 1}

Product Sophistication Index Relative to Communication Category

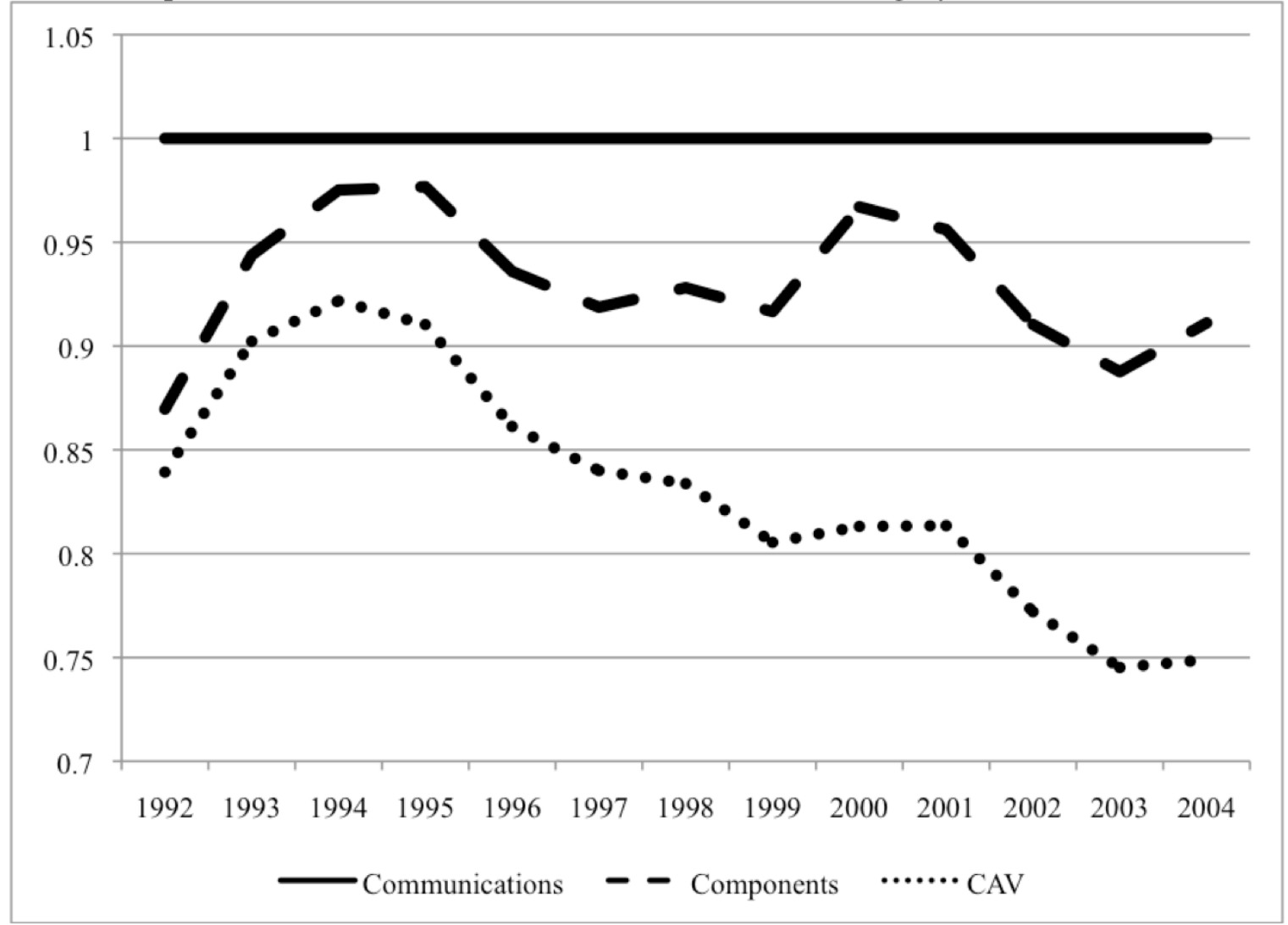


Figure 2

Country Technology Index Versus GDP Per Capita, 1992

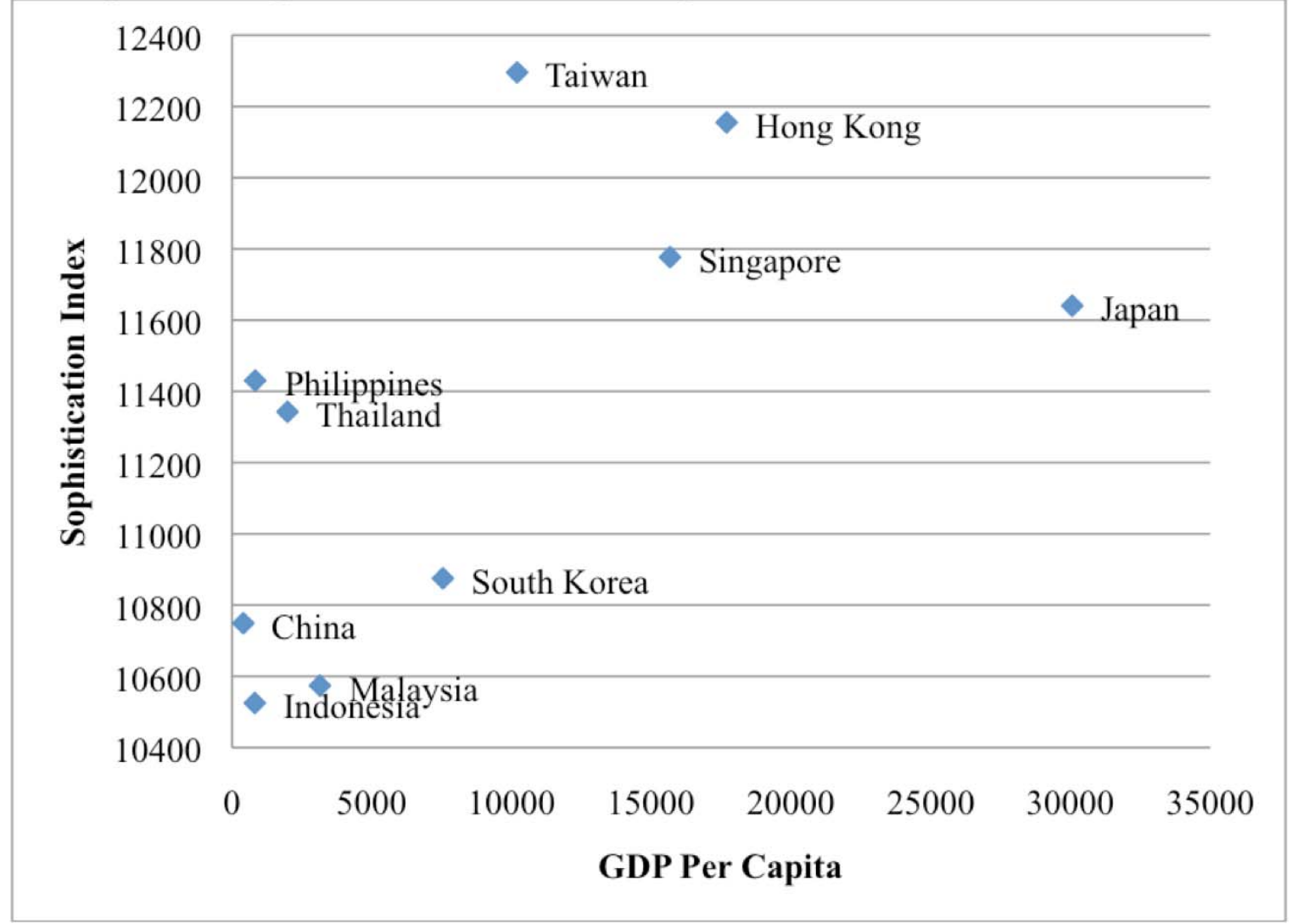


Figure 3

Country Technology Index Versus GDP Per Capita, 2004

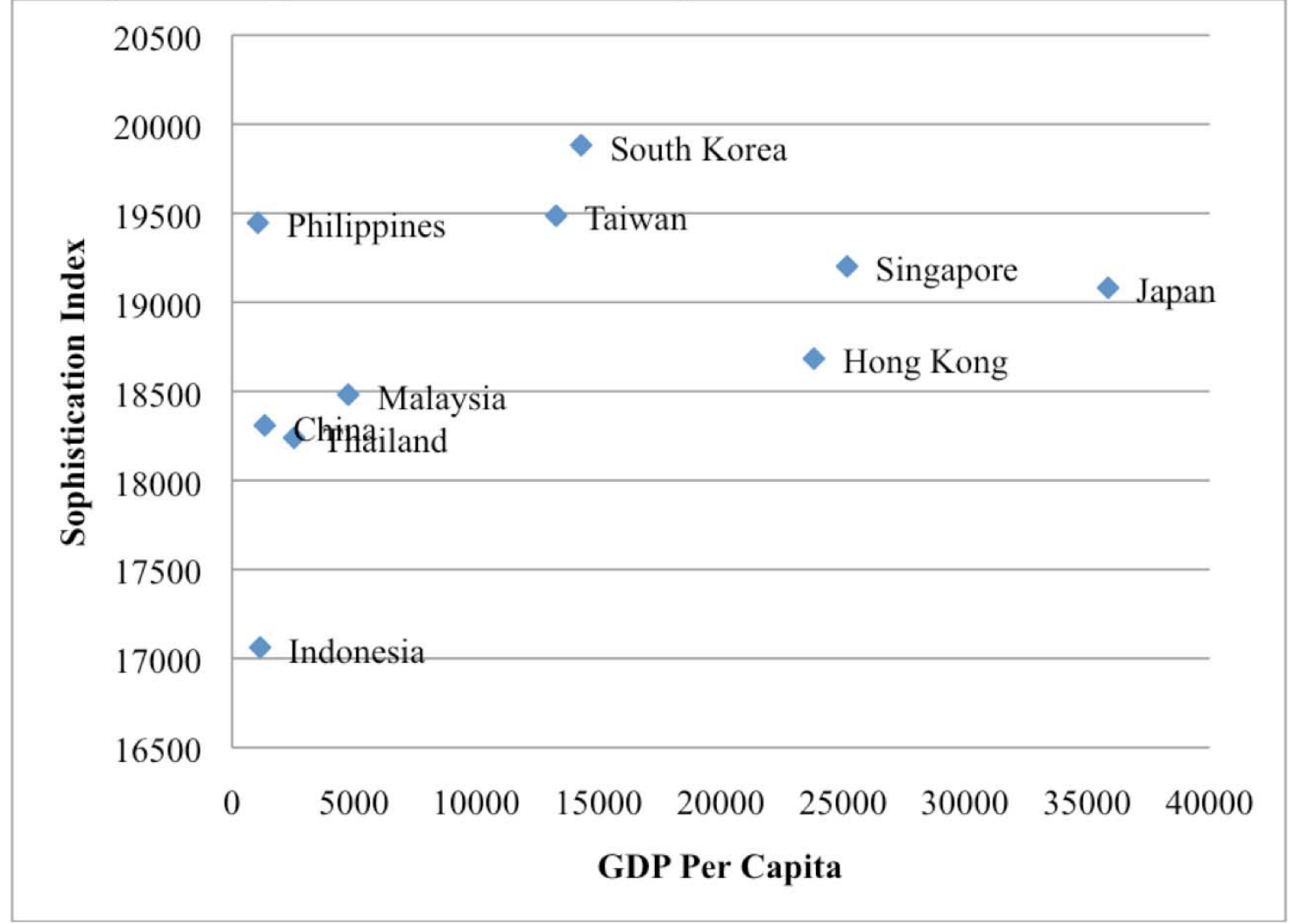




\section{Figure 4}

Intensity of China's processing imports (2007) versus severity of China's imports contraction (08Q1-09Q1), by country of origin.

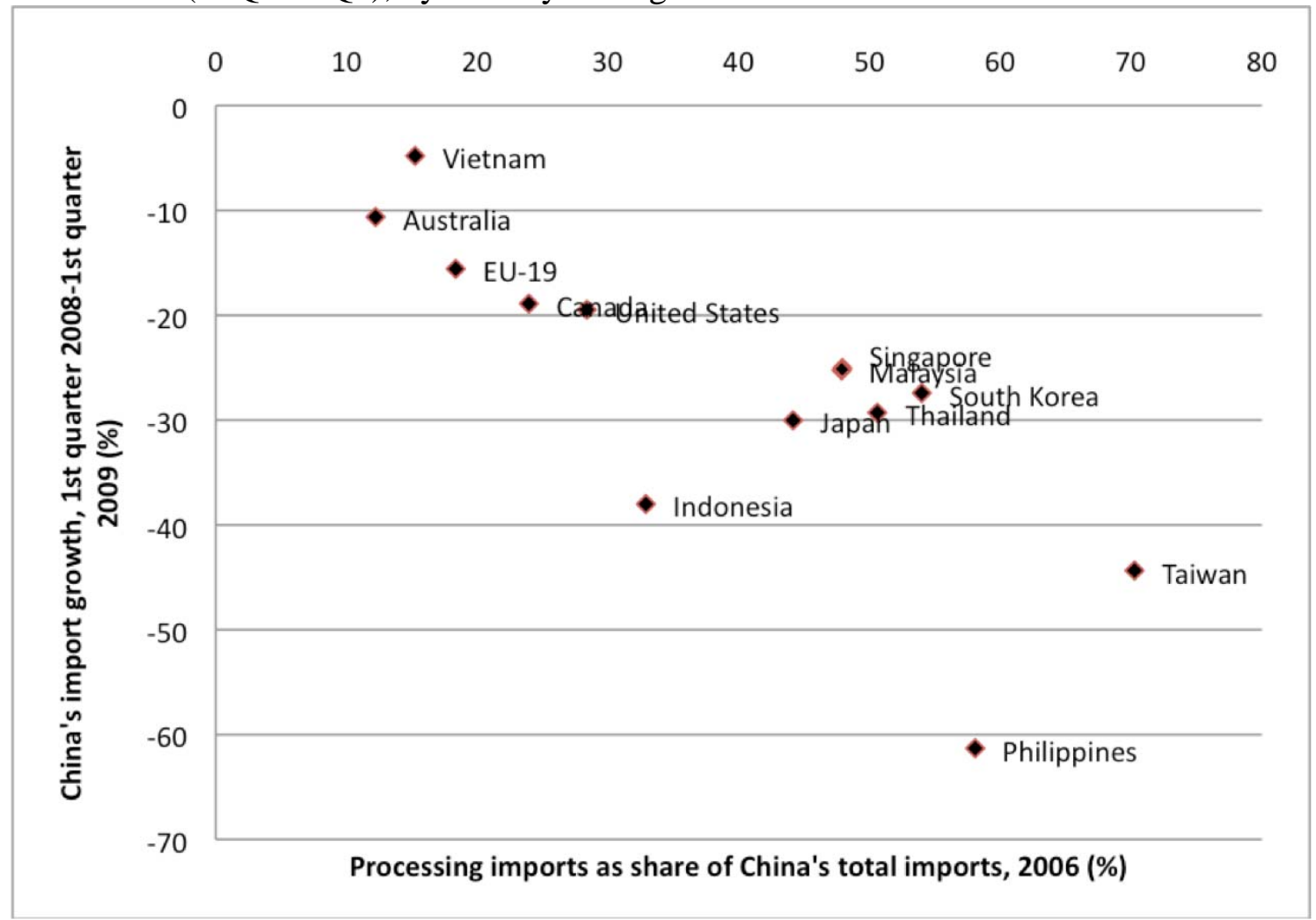


Table 1

Growth of Electronics Production, 1985-2005

\begin{tabular}{|c|c|c|c|c|c|c|c|}
\hline \multirow[b]{3}{*}{ Country } & \multicolumn{5}{|c|}{ Electronics Production } & \multirow{2}{*}{\multicolumn{2}{|c|}{$\begin{array}{c}\text { Share of world } \\
\text { electronics production } \\
(\%)\end{array}$}} \\
\hline & \multicolumn{3}{|c|}{ (US\$ Millions) } & \multicolumn{2}{|c|}{$\begin{array}{c}\text { Compound Annual } \\
\text { Growth }\end{array}$} & & \\
\hline & 1985 & 1995 & 2005 & 1985-1995 & 1995-2005 & 1995 & 2005 \\
\hline East Asia & - & 199310 & 538902 & - & 10 & 22 & 43 \\
\hline NIEs & - & 126280 & 193469 & - & 4 & 14 & 16 \\
\hline Hong Kong & 2647 & 7498 & 3036 & 11 & -9 & 1 & 0 \\
\hline Korea & 5571 & 47747 & 105429 & 24 & 8 & 5 & 9 \\
\hline Singapore & 3907 & 39091 & 47251 & 26 & 2 & 4 & 4 \\
\hline Taiwan & - & 31944 & 37752 & - & 2 & 3 & 3 \\
\hline ASEAN4 & 3695 & 48145 & 94963 & 29 & 7 & 5 & 8 \\
\hline Indonesia & 545 & 4451 & 10639 & 23 & 9 & 0 & 1 \\
\hline Malaysia & 1791 & 27569 & 47731 & 31 & 6 & 3 & 4 \\
\hline Philippines & 781 & 4109 & 13620 & 18 & 13 & 0 & 1 \\
\hline Thailand & 578 & 12016 & 22972 & 35 & 7 & 1 & 2 \\
\hline China & - & 24885 & 250471 & - & 26 & 3 & 20 \\
\hline United States & 146941 & 235359 & 221360 & 5 & -1 & 26 & 18 \\
\hline EU 15 & - & 168082 & 172224 & - & 0 & 18 & 14 \\
\hline Japan & 79155 & 244687 & 177845 & 12 & -3 & 27 & 14 \\
\hline Total Market & - & 916132 & 1238894 & - & 3 & 100 & 100 \\
\hline
\end{tabular}

Source: Reed Electronics Research, Yearbook of World Electronics Data. Adapted from Gangnes and Van Assche (2010). 
Table 2

Growth of Electronics Exports, 1980-2004

\begin{tabular}{|c|c|c|c|c|c|}
\hline \multirow[b]{2}{*}{ Country } & \multicolumn{2}{|c|}{$\begin{array}{c}\text { Value } \\
\text { (US\$ Millions) }\end{array}$} & \multirow{2}{*}{$\begin{array}{c}\text { Compound } \\
\text { Annual } \\
\text { Growth }\end{array}$} & \multicolumn{2}{|c|}{$\begin{array}{c}\text { Share of world } \\
\text { electronics } \\
\text { exports }(\%) \\
\end{array}$} \\
\hline & 1980 & 2004 & & 1980 & 2004 \\
\hline East Asia (Incl.)* & 12395 & 701962 & 18 & 13 & 49 \\
\hline East Asia (Excl.) & 9608 & 376325 & 17 & 10 & 26 \\
\hline NIEs & 10472 & 385334 & 16 & 11 & 27 \\
\hline Hong Kong & 2571 & 101455 & 17 & 3 & 7 \\
\hline Korea & 1860 & 91412 & 18 & 2 & 6 \\
\hline Singapore & 3018 & 94294 & 15 & 3 & 7 \\
\hline Taiwan & 3023 & 98173 & 16 & 3 & 7 \\
\hline ASEAN4 & 1838 & 119989 & 19 & 2 & 8 \\
\hline Indonesia & 103 & 7771 & 20 & 0 & 1 \\
\hline Malaysia & 1325 & 65218 & 18 & 1 & 5 \\
\hline Philippines & 72 & 15823 & 25 & 0 & 1 \\
\hline Thailand & 339 & 31176 & 21 & 0 & 2 \\
\hline China & 84 & 196639 & 38 & 0 & 14 \\
\hline United States & 17889 & 142720 & 9 & 19 & 10 \\
\hline EU 15 (Excl.) & 14990 & 134801 & 10 & 16 & 9 \\
\hline Japan & 19795 & 125927 & 8 & 21 & 9 \\
\hline Total Market & 96453 & 1429699 & 12 & 100 & 100 \\
\hline
\end{tabular}

Source: Statistics Canada World Trade Analyzer. Adapted from Gangnes and Van Assche (2010)

"Incl." indicates that trade flow includes intra-regional; "Excl." indicates intra-regional trade is excluded. 
Table 3

Origins and Destinations of Electronics Trade

\begin{tabular}{|c|c|c|c|c|c|c|c|c|}
\hline \multirow[b]{2}{*}{ Country } & \multicolumn{2}{|c|}{ East Asia } & \multicolumn{2}{|c|}{ United States } & \multicolumn{2}{|c|}{ EU-15 } & \multicolumn{2}{|c|}{ Japan } \\
\hline & 1980 & 2004 & 1980 & 2004 & 1980 & 2004 & 1980 & 2004 \\
\hline \multicolumn{9}{|l|}{ Exporting Region } \\
\hline East Asia (Incl) & 22.5 & 46.4 & 40.7 & 18.9 & 20.3 & 16.2 & 4.5 & 8.5 \\
\hline East Asia (Excl) & $\ldots$ & $\ldots$ & 52.4 & 35.3 & 26.2 & 30.2 & 5.8 & 15.8 \\
\hline United States & 11.0 & 31.9 & $\ldots$ & $\ldots$ & 43.8 & 17.6 & 6.7 & 5.7 \\
\hline EU-15 (Excl) & 10.3 & 22.9 & 11.2 & 12.9 & $\ldots$ & $\ldots$ & 2.3 & 2.3 \\
\hline Japan & 20.8 & 54.4 & 26.1 & 18.3 & 26.6 & 18.1 & $\ldots$ & $\ldots$ \\
\hline \multicolumn{9}{|l|}{ Importing Region } \\
\hline East Asis (Incl) & 26.2 & 68.1 & 18.5 & 9.5 & 14.5 & 6.5 & 38.6 & 14.3 \\
\hline East Asia (Excl) & $\ldots$ & $\ldots$ & 25.0 & 29.9 & 19.7 & 20.3 & 52.3 & 45.0 \\
\hline United States & 37.0 & 58.6 & $\ldots$ & $\ldots$ & 12.4 & 7.7 & 37.9 & 10.2 \\
\hline EU15 (Excl) & 14.4 & 55.6 & 44.9 & 12.3 & $\ldots$ & $\ldots$ & 30.2 & 11.2 \\
\hline Japan & 24.7 & 82.9 & 52.8 & 11.3 & 15.0 & 4.4 & $\ldots$ & $\ldots$ \\
\hline
\end{tabular}

Source: Statistics Canada World Trade Analyzer.

*"Incl." indicates that intra-regional trade is included; "Excl." indicates intra-regional trade is excluded. 
Table 4

Intra-regional and Inter-regional Electronics Trade (2004)

\begin{tabular}{lrrrrrr}
\hline Country & NIEs & \multicolumn{7}{c}{ ASEAN4 } & China & US & EU (Excl) Japan \\
\hline \multicolumn{7}{c}{ Final Goods } \\
Export shares & & \multicolumn{7}{c}{ J } & & & \\
$\quad$ NIEs & 12.3 & 6.2 & 20.2 & 20.1 & 22.1 & 6.9 \\
ASEAN4 & 18.3 & 4.7 & 9.7 & 32.6 & 15.1 & 9.1 \\
China & 23.4 & 4.0 & $\ldots$ & 27.6 & 22.4 & 11.8 \\
US & 9.1 & 2.8 & 4.1 & $\ldots$ & 25.7 & 6.9 \\
EU15 (Excl) & 6.8 & 2.5 & 3.1 & 15.7 & $\ldots$ & 2.8 \\
Japan & 15.2 & 5.6 & 10.4 & 31.2 & 25.8 & $\ldots$ \\
& & & & & & \\
Import Shares & & & & & & \\
NIEs & 23.5 & 15.2 & 40.1 & 7.6 & 4.4 & 7.5 \\
ASEAN4 & 39.6 & 13.2 & 22.8 & 7.9 & 5.3 & 9.2 \\
China & 66.4 & 13.9 & $\ldots$ & 5.9 & 3.4 & 8.8 \\
US & 21.3 & 15.0 & 26.2 & $\ldots$ & 5.5 & 8.5 \\
EU15 (Excl) & 27.3 & 8.1 & 24.9 & 14.0 & $\ldots$ & 8.2 \\
Japan & 26.9 & 15.4 & 41.0 & 11.7 & 3.6 & $\ldots$
\end{tabular}

Intermediate Goods

\begin{tabular}{lrrrrrr} 
Export shares & & & & & & \\
NIEs & 22.7 & 10.2 & 28.9 & 12.3 & 10.9 & 6.5 \\
ASEAN4 & 31.2 & 7.3 & 11.6 & 14.8 & 15.6 & 11.2 \\
China & 40.0 & 4.7 & $\ldots$ & 19.8 & 15.8 & 9.7 \\
US & 20.9 & 15.6 & 5.4 & $\ldots$ & 12.9 & 4.9 \\
EU15 (Excl) & 11.9 & 8.1 & 7.5 & 11.7 & $\ldots$ & 2.1 \\
Japan & 32.6 & 11.8 & 18.0 & 13.8 & 15.5 & $\ldots$ \\
& & & & & & \\
Import Shares & & & & & & \\
NIEs & 33.6 & 11.3 & 19.1 & 10.5 & 6.4 & 17.5 \\
ASEAN4 & 38.7 & 6.8 & 5.8 & 20.1 & 11.1 & 16.2 \\
China & 66.6 & 6.6 & $\ldots$ & 4.2 & 6.3 & 15.0 \\
US & 30.1 & 8.9 & 15.5 & $\ldots$ & 10.3 & 12.2 \\
EU15 (Excl) & 27.8 & 9.7 & 12.9 & 11.1 & $\ldots$ & 14.2 \\
Japan & 43.1 & 18.3 & 20.8 & 11.2 & 5.1 & $\ldots$ \\
\hline
\end{tabular}

Source: Statistics Canada World Trade Analyzer.

*"Excl." indicates intra-regional trade is excluded. 
Table 5

Export RCAs

\begin{tabular}{|c|c|c|c|c|c|c|c|c|c|c|c|}
\hline \multirow[b]{2}{*}{ SITC Rev. 2} & \multicolumn{6}{|c|}{ Final Goods } & \multicolumn{5}{|c|}{ Intermediate Goods } \\
\hline & 751 & 752 & 761 & 7641 & 7642 & $\begin{array}{l}\text { Final } \\
\text { Total }\end{array}$ & 759 & 7649 & 772 & 776 & $\begin{array}{c}\text { Interm } \\
\text { Total }\end{array}$ \\
\hline Description & $\begin{array}{c}\text { Office } \\
\text { machines }\end{array}$ & $\begin{array}{c}\text { Data } \\
\text { processing } \\
\text { equip }\end{array}$ & Televisions & $\begin{array}{c}\text { Telephone, } \\
\text { telegraph }\end{array}$ & $\begin{array}{c}\text { Sound } \\
\text { Equipment }\end{array}$ & & $\begin{array}{c}\text { Office } \\
\text { Machine } \\
\text { Parts } \\
\end{array}$ & $\begin{array}{c}\text { Telecomm } \\
\text { Parts } \\
\end{array}$ & $\begin{array}{c}\text { Passive } \\
\text { components }\end{array}$ & $\begin{array}{c}\text { Active } \\
\text { components }\end{array}$ & \\
\hline NIEs & 1.15 & 0.66 & 0.56 & 0.54 & 0.68 & 0.80 & 0.81 & 0.95 & 0.61 & 1.49 & 1.14 \\
\hline Hong Kong & 1.53 & 0.36 & 0.28 & 1.01 & 1.34 & 0.80 & 2.03 & 1.30 & 0.89 & 1.00 & 1.11 \\
\hline Korea Rp & 1.01 & 0.62 & 1.12 & 0.27 & 0.62 & 0.77 & 0.23 & 1.67 & 0.31 & 1.09 & 1.17 \\
\hline Singapore & 0.98 & 0.91 & 0.17 & 0.29 & 0.35 & 0.81 & 0.53 & 0.47 & 0.45 & 1.97 & 1.14 \\
\hline Taiwan & 1.06 & 0.78 & 0.71 & 0.57 & 0.36 & 0.84 & 0.35 & 0.39 & 0.77 & 1.91 & 1.13 \\
\hline ASEAN4 & 1.05 & 1.22 & 0.98 & 1.04 & 0.82 & 1.12 & 0.49 & 0.57 & 0.59 & 1.29 & 0.90 \\
\hline Indonesia & 0.96 & 1.23 & 1.19 & 0.47 & 2.90 & 1.11 & 1.55 & 1.33 & 0.91 & 0.42 & 0.86 \\
\hline Malaysia & 1.04 & 1.04 & 0.94 & 0.74 & 0.87 & 1.01 & 0.24 & 0.52 & 0.68 & 1.47 & 0.97 \\
\hline Philippines & 1.22 & 1.44 & 0.02 & 0.21 & 0.22 & 1.13 & 1.10 & 0.35 & 0.13 & 1.69 & 0.93 \\
\hline Thailand & 1.00 & 1.48 & 1.51 & 2.22 & 0.51 & 1.36 & 0.43 & 0.61 & 0.54 & 0.94 & 0.74 \\
\hline China & 1.08 & 1.75 & 0.85 & 1.26 & 1.83 & 1.41 & 0.58 & 1.26 & 0.49 & 0.34 & 0.72 \\
\hline USA & 1.08 & 0.92 & 0.32 & 1.29 & 1.17 & 0.95 & 0.74 & 0.63 & 1.08 & 1.39 & 1.04 \\
\hline Japan & 1.01 & 0.37 & 1.15 & 0.15 & 0.32 & 0.63 & 1.57 & 1.13 & 1.37 & 1.32 & 1.26 \\
\hline
\end{tabular}

Source: Authors' calculations based on data from Statistics Canada World Trade Analyzer.

Note: For more complete category descriptions, see footnote 3. 
Table 6

Import RCAs

\begin{tabular}{|c|c|c|c|c|c|c|c|c|c|c|c|}
\hline \multirow[b]{2}{*}{ SITC Rev. 2} & \multicolumn{6}{|c|}{ Final Goods } & \multicolumn{5}{|c|}{ Intermediate Goods } \\
\hline & 751 & 752 & 761 & 7641 & 7642 & $\begin{array}{l}\text { Final } \\
\text { Total }\end{array}$ & 759 & 7649 & 772 & 776 & $\begin{array}{c}\text { Interm } \\
\text { Total }\end{array}$ \\
\hline Description & $\begin{array}{c}\text { Office } \\
\text { machines }\end{array}$ & $\begin{array}{c}\text { Data } \\
\text { processing } \\
\text { equip }\end{array}$ & Televisions & $\begin{array}{c}\text { Telephone, } \\
\text { telegraph }\end{array}$ & $\begin{array}{c}\text { Sound } \\
\text { Equipment }\end{array}$ & & $\begin{array}{c}\text { Office } \\
\text { Machine } \\
\text { Parts }\end{array}$ & $\begin{array}{c}\text { Telecomm } \\
\text { Parts }\end{array}$ & $\begin{array}{c}\text { Passive } \\
\text { components }\end{array}$ & $\begin{array}{c}\text { Active } \\
\text { components }\end{array}$ & \\
\hline NIEs & 1.02 & 0.53 & 0.31 & 0.53 & 0.81 & 0.67 & 0.70 & 0.75 & 0.80 & 1.81 & 1.23 \\
\hline Hong Kong & 1.12 & 0.67 & 0.37 & 0.67 & 1.06 & 0.80 & 0.85 & 1.00 & 0.81 & 1.40 & 1.15 \\
\hline Korea Rp & 0.52 & 0.48 & 0.23 & 0.42 & 0.74 & 0.47 & 0.67 & 0.65 & 0.87 & 2.17 & 1.37 \\
\hline Singapore & 1.35 & 0.42 & 0.37 & 0.46 & 0.75 & 0.73 & 0.64 & 0.61 & 0.69 & 1.88 & 1.19 \\
\hline Taiwan & 0.78 & 0.38 & 0.13 & 0.42 & 0.34 & 0.49 & 0.41 & 0.42 & 0.85 & 2.36 & 1.36 \\
\hline ASEAN4 & 1.13 & 0.27 & 0.10 & 0.45 & 0.49 & 0.55 & 0.63 & 0.51 & 0.93 & 2.16 & 1.32 \\
\hline Indonesia & 0.38 & 0.49 & 0.56 & 2.79 & 1.66 & 0.65 & 0.62 & 2.09 & 1.68 & 0.37 & 1.24 \\
\hline Malaysia & 1.12 & 0.32 & 0.06 & 0.37 & 0.51 & 0.57 & 0.58 & 0.46 & 0.91 & 2.20 & 1.31 \\
\hline Philippines & 0.93 & 0.11 & 0.07 & 0.26 & 0.21 & 0.38 & 0.56 & 0.27 & 0.58 & 2.75 & 1.43 \\
\hline Thailand & 1.48 & 0.30 & 0.19 & 0.55 & 0.59 & 0.70 & 0.84 & 0.71 & 1.26 & 1.65 & 1.22 \\
\hline China & 1.11 & 0.48 & 0.05 & 0.27 & 0.37 & 0.63 & 1.30 & 0.86 & 1.11 & 1.67 & 1.27 \\
\hline USA & 1.01 & 1.37 & 1.94 & 1.18 & 1.35 & 1.29 & 0.87 & 1.12 & 0.81 & 0.51 & 0.79 \\
\hline Japan & 0.98 & 1.29 & 0.70 & 0.97 & 1.32 & 1.11 & 1.45 & 0.75 & 0.61 & 1.15 & 0.92 \\
\hline
\end{tabular}

Source: Authors' calculations based on data from Statistics Canada World Trade Analyzer.

Note: For more complete category descriptions, see footnote 3. 


\section{Table 7}

\section{Categories of Electronics Production}

\begin{tabular}{ll}
\hline Category & Type of Products \\
\hline Electronic data processing & Computers, peripherals \\
Office equipment & Photocopiers, electronic calculators \\
Radio communications and radar & Mobile radio telephones, pagers \\
Telecommunications & Telephones, fax, answering machines \\
Video equipment & Television, video camera, DVD player \\
Audio equipment & Portable audio, car audio, CD player \\
Active components & Integrated circuits, diodes, transistors \\
Passive components & Printed circuit boards, relays, switches \\
Other components & Microphones, loudspeakers, amplifiers \\
\hline
\end{tabular}




\section{Table 8}

Product sophistication indices

\begin{tabular}{|c|c|c|c|c|}
\hline \multirow[b]{2}{*}{ Category } & \multicolumn{2}{|c|}{$\begin{array}{l}\text { Share of world } \\
\text { electronics } \\
\text { production }\end{array}$} & \multicolumn{2}{|c|}{$\begin{array}{c}\text { Relative } \\
\text { sophistication }\end{array}$} \\
\hline & 1992 & 2004 & 1992 & 2004 \\
\hline Communications & 26.2 & 26.6 & 1.00 & 0.97 \\
\hline Radio Communications \& Radar & 14.5 & 19.6 & 1.00 & 1.00 \\
\hline Telecommunications & 11.7 & 7.0 & 0.98 & 0.87 \\
\hline Components & 29.5 & 32.4 & 0.86 & 0.88 \\
\hline Passive components & 8.5 & 7.1 & 0.95 & 0.93 \\
\hline Other components & 6.0 & 4.4 & 0.95 & 0.92 \\
\hline Active components & 15.0 & 20.8 & 0.78 & 0.85 \\
\hline Computers, Audio and video & 44.3 & 41.0 & 0.85 & 0.72 \\
\hline Electronic Data Processing & 29.8 & 30.7 & 0.95 & 0.81 \\
\hline Office equipment & 2.7 & 1.0 & 0.85 & 0.74 \\
\hline Audio equipment & 3.7 & 2.2 & 0.57 & 0.53 \\
\hline Video equipment & 8.0 & 7.1 & 0.51 & 0.39 \\
\hline
\end{tabular}

Source: Authors' calculations based on data from Reed Electronics Research. 


\section{Table 9}

Production Intensity Indices

\begin{tabular}{|c|c|c|c|c|c|c|}
\hline & \multicolumn{2}{|c|}{ Communications } & \multicolumn{2}{|c|}{ Components } & \multicolumn{2}{|c|}{ Computers, Audio\&Video } \\
\hline & 1992 & 2004 & 1992 & 2004 & 1992 & 2004 \\
\hline Japan & 1.15 & 1.12 & 0.96 & 1.29 & 0.99 & 0.70 \\
\hline NIEs & 0.72 & 1.10 & 1.07 & 1.27 & 1.02 & 0.74 \\
\hline South Korea & 0.84 & 1.66 & 1.35 & 1.12 & 0.78 & 0.63 \\
\hline Taiwan & 0.84 & 1.03 & 1.01 & 1.49 & 1.03 & 0.57 \\
\hline Singapore & 0.30 & 0.25 & 0.83 & 1.27 & 1.30 & 1.08 \\
\hline Hong Kong & 1.17 & 1.05 & 0.88 & 0.95 & 1.04 & 1.02 \\
\hline$A S E A N-4$ & 1.02 & 0.43 & 1.02 & 1.27 & 0.98 & 1.03 \\
\hline Philippines & 1.64 & 0.44 & 1.58 & 1.55 & 0.40 & 0.77 \\
\hline Malaysia & 0.90 & 0.44 & 0.96 & 1.31 & 0.90 & 0.97 \\
\hline Thailand & 0.90 & 0.50 & 0.64 & 1.00 & 1.30 & 1.21 \\
\hline Indonesia & 1.56 & 0.44 & 0.63 & 0.94 & 1.13 & 1.28 \\
\hline China & 1.21 & 0.98 & 0.81 & 0.44 & 1.09 & 1.48 \\
\hline
\end{tabular}

Source: Authors' calculations based on data from Reed Electronics Research 
Table 10

Electronics Export Shares

\begin{tabular}{|c|c|c|c|c|}
\hline \multirow[b]{2}{*}{ Country } & \multicolumn{2}{|c|}{$\begin{array}{c}\text { Electronics Exports as Share of } \\
\text { Manufacturing Exports }\end{array}$} & \multicolumn{2}{|c|}{$\begin{array}{c}\text { Electr. Final Good Exports as } \\
\text { Share of Manufacturing } \\
\text { Exports }\end{array}$} \\
\hline & 1980 & 2004 & 1980 & 2004 \\
\hline East Asia (Incl.)* & 14.4 & 39.2 & 2.8 & 15.9 \\
\hline East Asia (Excl.)* & 14.1 & 34.6 & 2.9 & 17.5 \\
\hline NIEs & 16.1 & 42.6 & 3.6 & 13.5 \\
\hline Hong Kong & 13.2 & 38.3 & 3.4 & 12.1 \\
\hline Korea Rp. & 11.1 & 35.6 & 4.1 & 10.8 \\
\hline Singapore & 29.6 & 57.7 & 4.9 & 18.4 \\
\hline Taiwan & 16.2 & 44.8 & 2.7 & 14.8 \\
\hline ASEAN4 & 17.7 & 42.9 & 0.2 & 19.0 \\
\hline Indonesia & 6.9 & 18.9 & 0.1 & 8.3 \\
\hline Malaysia & 34.8 & 60.7 & 0.3 & 24.2 \\
\hline Philippines & 3.0 & 39.4 & 0.1 & 17.5 \\
\hline Thailand & 12.6 & 34.4 & 0.4 & 18.5 \\
\hline China & 0.8 & 32.3 & 0.1 & 18.1 \\
\hline United States & 10.6 & 19.0 & 6.2 & 7.1 \\
\hline EU-15 (Excl.)* & 6.0 & 11.0 & 2.1 & 3.3 \\
\hline Japan & 14.7 & 21.0 & 4.3 & 5.3 \\
\hline Total Market & 8.0 & 18.9 & 3.2 & 7.5 \\
\hline
\end{tabular}

Source: Statistics Canada World Trade Analyzer.

"Incl." indicates that trade flow includes intra-regional; "Excl." indicates intra-regional trade is excluded. 
Table 11

Electronics Trade Dependence

\begin{tabular}{|c|c|c|c|c|c|c|}
\hline \multirow[b]{2}{*}{ Country } & \multicolumn{2}{|c|}{$\begin{array}{l}\text { Electronics Exports } \\
\text { as Share of GDP }\end{array}$} & \multicolumn{2}{|c|}{$\begin{array}{c}\text { Electr. Final Good } \\
\text { Exports as Share of } \\
\text { GDP }\end{array}$} & \multicolumn{2}{|c|}{$\begin{array}{l}\text { Electr. Final Good } \\
\text { Exports to U.S. as } \\
\text { Share of GDP }\end{array}$} \\
\hline & 1980 & 2004 & 1980 & 2004 & 1980 & 2004 \\
\hline East Asia (Incl.)* & 2.0 & 18.3 & 0.4 & 7.4 & 0.2 & 1.9 \\
\hline NIEs & 7.3 & 30.0 & 1.6 & 9.5 & 0.7 & 1.9 \\
\hline Hong Kong & 9.0 & 61.2 & 2.3 & 19.3 & 1.2 & 2.3 \\
\hline Korea Rp. & 3.0 & 13.4 & 1.1 & 4.1 & 0.5 & 0.8 \\
\hline Singapore & 25.8 & 87.8 & 4.3 & 28.0 & 0.9 & 7.2 \\
\hline Taiwan & 7.3 & 29.6 & 1.2 & 9.8 & 0.5 & 2.3 \\
\hline ASEAN4 & 1.0 & 19.2 & 0.0 & 8.5 & 0.0 & 2.8 \\
\hline Indonesia & 0.1 & 3.0 & 0.0 & 1.3 & 0.0 & 0.2 \\
\hline Malaysia & 5.4 & 55.1 & 0.0 & 21.9 & 0.0 & 9.5 \\
\hline Philippines & 0.2 & 18.2 & 0.0 & 8.1 & 0.0 & 1.3 \\
\hline Thailand & 1.0 & 19.3 & 0.0 & 10.4 & 0.0 & 2.8 \\
\hline China & 0.0 & 10.2 & 0.0 & 5.7 & 0.0 & 1.6 \\
\hline Japan & 1.8 & 2.7 & 0.5 & 0.7 & 0.1 & 0.2 \\
\hline
\end{tabular}

Source: Statistics Canada World Trade Analyzer; IMF and World Bank for GDP.

"Incl." indicates that intra-regional trade is included. 
Table 12

China's Processing Trade during the 2008-2009 Economic Crisis

\begin{tabular}{|c|c|c|c|c|c|c|}
\hline & \multicolumn{2}{|c|}{$\begin{array}{l}\text { Processing exports } \\
\text { (US\$ billion) }\end{array}$} & \multirow{2}{*}{$\begin{array}{c}\text { Processing } \\
\text { exports growth } \\
(\%) \\
\text { 08Q1/09Q1 }\end{array}$} & \multicolumn{2}{|c|}{$\begin{array}{l}\text { Processing imports } \\
\text { (US\$ billion) }\end{array}$} & \multirow{2}{*}{$\begin{array}{c}\text { Processing } \\
\text { imports growth } \\
(\%) \\
\text { 08Q1/09Q1 }\end{array}$} \\
\hline & 08Q1 & 09Q1 & & 08Q1 & 09Q1 & \\
\hline High technology & 78.27 & 57.25 & -26.9 & 45.9 & 29.08 & -36.6 \\
\hline Aircraft & 0.21 & 0.23 & 8.6 & 0.11 & 0.09 & -17.8 \\
\hline Pharmaceuticals & 0.37 & 0.36 & -3.3 & 0.08 & 0.09 & 24 \\
\hline Office and computing machinery & 30.66 & 23.8 & -22.4 & 3.59 & 2.43 & -32.5 \\
\hline Radio, TV and comm. Equipment & 38.5 & 27.82 & -27.7 & 29.71 & 20.25 & -31.9 \\
\hline Medical, precision and optical ins. & 8.54 & 5.05 & -40.9 & 12.41 & 6.22 & -49.8 \\
\hline Medium-high technology & 34 & 24.85 & -26.9 & 13.58 & 9.79 & -27.9 \\
\hline Electrical machinery & 10.52 & 7.43 & -29.4 & 6.27 & 4.34 & -30.7 \\
\hline Motor vehicles & 3.37 & 1.37 & -59.4 & 0.26 & 0.17 & -35 \\
\hline Chemicals & 2.47 & 2.01 & -18.4 & 2.1 & 1.41 & -32.9 \\
\hline Other transport equipment & 0.87 & 0.79 & -9.5 & 0.07 & 0.06 & -13.1 \\
\hline Machinery and equipment & 16.77 & 13.26 & -21 & 4.89 & 3.81 & -22 \\
\hline Medium-low technology & 12.68 & 12.04 & -5.1 & 10.12 & 5.69 & -43.8 \\
\hline Shipbuilding and repairing & 3.36 & 5.3 & 57.5 & 0.01 & 0.04 & 377.6 \\
\hline Rubber and plastic products & 4.57 & 3.59 & -21.5 & 1.59 & 1.09 & -31.5 \\
\hline Petroleum products & 0.05 & 0.04 & -14.7 & 0.04 & 0.18 & 395.9 \\
\hline Non-metallic mineral products & 0.71 & 0.49 & -31.1 & 0.66 & 0.37 & -44.5 \\
\hline Metal products & 3.98 & 2.62 & -34.3 & 7.82 & 4.01 & -48.7 \\
\hline Low technology & 22.68 & 19.38 & -14.6 & 6.58 & 4.69 & -28.7 \\
\hline Manufacturing & 8.17 & 6.79 & -16.9 & 0.73 & 0.52 & -27.7 \\
\hline Paper and paper products & 1.38 & 0.98 & -29 & 1.28 & 0.72 & -44 \\
\hline Printing and publishing & 0.32 & 0.32 & -1.3 & 0.06 & 0.05 & -13.3 \\
\hline Food, beverages and tobacco & 1.32 & 1.35 & 2.5 & 0.71 & 0.5 & -29.5 \\
\hline Textiles, apparel and leather & 11.49 & 9.94 & -13.5 & 3.8 & 2.9 & -23.8 \\
\hline Other & 4.55 & 2.63 & -42.3 & 11.76 & 6.85 & -41.8 \\
\hline Total & 152.18 & 116.15 & -23.7 & 87.94 & 56.1 & -36.2 \\
\hline
\end{tabular}

Source: Ma and Van Assche (forthcoming). 
Table A

Production intensity indices for detailed electronics subcategories

\begin{tabular}{lccccccccc}
\hline \multicolumn{1}{c}{ 2004 } & COM & TEL & PAS & OTH & ACT & EDP & OFF & AUD & VID \\
\hline Japan & & & & & & & & & \\
Korea Rp. & 1.16 & 0.97 & 1.51 & 0.74 & 1.34 & 0.59 & 1.23 & 0.56 & 1.16 \\
Taiwan & 2.00 & 0.31 & 0.51 & 0.66 & 1.37 & 0.67 & 0.53 & 0.31 & 0.59 \\
Singapore & 0.98 & 1.20 & 1.66 & 0.54 & 1.63 & 0.58 & 0.06 & 0.27 & 0.69 \\
Hong Kong & 0.23 & 0.33 & 0.60 & 1.08 & 1.49 & 1.37 & 0.63 & 0.80 & 0.06 \\
Philippines & 0.58 & 2.88 & 2.45 & 1.80 & 0.37 & 0.70 & 6.20 & 6.26 & 0.00 \\
Malaysia & 0.53 & 0.11 & 0.97 & 0.41 & 1.94 & 0.94 & 0.66 & 0.51 & 0.15 \\
Thailand & 0.36 & 0.72 & 0.86 & 1.26 & 1.45 & 0.91 & 0.28 & 1.89 & 0.94 \\
Indonesia & 0.23 & 1.54 & 0.87 & 1.29 & 0.99 & 1.21 & 0.76 & 1.28 & 1.20 \\
China & 0.40 & 0.61 & 1.34 & 1.55 & 0.71 & 0.88 & 1.23 & 1.88 & 2.72 \\
& 0.85 & 1.49 & 0.74 & 1.36 & 0.18 & 1.52 & 1.36 & 1.56 & 1.27 \\
& & & & & & & & & \\
Japan & & & & & & & & & \\
Korea Rp. & 0.63 & 1.00 & 0.65 & 1.34 & 1.64 & 0.49 & 0.39 & 1.11 & 1.48 \\
Taiwan & 0.71 & 0.94 & 1.62 & 1.07 & 0.74 & 1.47 & 0.42 & 0.56 & 0.27 \\
Singapore & 0.44 & 0.19 & 0.47 & 0.66 & 1.05 & 1.71 & 0.64 & 0.91 & 0.58 \\
Hong Kong & 1.42 & 0.98 & 1.14 & 2.06 & 0.35 & 1.17 & 1.67 & 1.82 & 0.07 \\
Philippines & 2.49 & 0.97 & 0.68 & 0.36 & 2.41 & 0.36 & 0.24 & 0.49 & 0.50 \\
Malaysia & 0.84 & 0.95 & 0.65 & 0.54 & 1.62 & 0.46 & 0.31 & 2.52 & 1.22 \\
Thailand & 0.73 & 1.03 & 0.70 & 0.44 & 0.69 & 1.33 & 0.99 & 0.23 & 1.93 \\
Indonesia & 1.54 & 1.58 & 0.35 & 1.38 & 0.48 & 0.48 & 0.96 & 1.63 & 2.66 \\
China & 1.09 & 1.31 & 1.19 & 1.28 & 0.47 & 0.48 & 1.49 & 2.64 & 1.71 \\
\hline Sourc: Aus & & & & & & & & & \\
\end{tabular}

Source: Authors' calculations based on data from Reed Electronics Research. 